\title{
Changes in in Vitro Methane Production and Fatty Acid Profiles in Response to Cakalang Fish Oil Supplementation
}

\author{
E. H. B. Sondakh*, M. R. Waani, \& J. A. D. Kalele \\ Faculty of Animal Science, Sam Ratulangi University \\ Manado, North Sulawesi, Indonesia (95115) \\ (Received 08-10-2017; Reviewed 20-11-2017; Accepted 14-12-2017)
}

\begin{abstract}
This experiment was conducted to determine the effect of cakalang fish oil addition in ruminant feed on in vitro methane production and fatty acid profiles. This experiment consisted of four treatments which were R0 : feed composing of forage and concentrate at a ratio of $60 \%: 40 \%$ without cakalang fish oil (CFO) addition as control feed; R1: R0 added with CFO at 2.5\%; R2: R0 added with CFO at $5 \%$, and R3: R0 added with CFO at $7.5 \%$. Fermentation with rumen fluid was done using the Hohenheim Gas Test (HGT); feeds were incubated at $39{ }^{\circ} \mathrm{C}$ for 72 hours. At the end of fermentation, samples were obtained and methane production and fatty acid profiles were determined. The experiment was conducted in completely randomised design with four replications. Data were analysed using analysis of variance and differences among treatment means were analysed using Duncan multiple range test. Results showed that CFO supplementation affected $(\mathrm{P}<0.05)$ methane production, protozoa numbers and $\mathrm{NH}_{3}$ concentration; whereas the other parameters, i.e. VFA concentration, $\mathrm{pH}$, and microbial protein were not affected. Some fatty acid profiles were influenced by treatments, such as palmitic, stearic, oleic, linoleic, and linolenic $(\mathrm{P}<0.05)$, while others, i.e. lauric and miristic were not affected. It is concluded that the best level of CFO supplementation is $5 \%$ as this level reduces methane production and increases unsaturated fatty acids without any negative effects on other variables measured.
\end{abstract}

Keywords: cakalang fish oil, fatty acids, in vitro fermentation, methane, gas test

\begin{abstract}
ABSTRAK
Penelitian ini dilaksanakan untuk menguji pengaruh suplementasi minyak ikan cakalang ke dalam ransum ternak ruminansia terhadap produksi gas metan dan profil asam lemak in vitro. Perlakuan terdiri atas empat perlakuan ransum, yaitu R0: ransum yang terdiri atas hijauan dan konsentrat dengan rasio $60 \%$ : $40 \%$ tanpa penambahan minyak ikan cakalang (MIC) sebagai ransum kontrol; R1: R0 yang disuplementasi dengan 2,5\% MIC; R2: R0 yang disuplementasi dengan 5\% MIC; R3: R0 yang disuplementasi dengan 7,5\% MIC. Fermentasi in vitro dilakukan dengan menggunakan tes gas Hohenheim (TGH); ransum perlakuan difermentasi pada suhu $39{ }^{\circ} \mathrm{C}$ selama 72 jam. Pada waktu akhir fermentasi, dilakukan pengambilan sampel untuk pengukuran produksi gas metan dan profil asam lemak. Rancangan percobaan yang digunakan adalah rancangan acak lengkap dengan empat replikasi. Data dianalisis dengan analisis ragam, dan perbedaan di antara perlakuan diuji dengan uji jarak berganda Duncan. Hasil percobaan menunjukkan bahwa perlakuan mempengaruhi produksi gas metan, jumlah protozoa, dan konsentrasi $\mathrm{NH}_{3}(\mathrm{P}<0,05)$; sedangkan peubah lainnya, seperti konsentrasi VFA, $\mathrm{pH}$, and sintesis protein mikrobia tidak memberikan pengaruh yang nyata. Beberapa profil asam lemak yang dipengaruhi oleh perlakuan adalah palmitat, stearat, oleat, linoleat, dan linolenat, serta konsentrasi SAFA dan UFA $(\mathbf{P}<0,05)$. Beberapa asam lemak lainnya, seperti asam laurat dan miristat, menunjukkan tidak berbeda nyata. Dapat disimpulkan bahwa taraf terbaik suplementasi MIC adalah $5 \%$ karena dapat menurunkan produksi gas metan dan meningkatkan asam lemak tak jenuh tanpa menyebabkan efek negatif pada variabel lainnya.
\end{abstract}

Kata kunci: minyak ikan cakalang, asam lemak, fermentasi in vitro, metan, tes gas

${ }^{*}$ Corresponding author:

E-mail: erwin_sondakh@yahoo.com 


\section{INTRODUCTION}

Methane is gas compound produced as a result of feed fermentation by rumen microbes. Methane is produced by protozoa as one of microbes in the rumen (Dohme et al., 1999). Methanogenic bacteria are the other rumen microbes producing methane and are found to attach to ciliate protozoa to obtain a constant supply of hydrogen for producing methane (Kamra, 2005). In their symbiosis, the protozoa released the hydrogen which were then transferred to the methanogenic bacteria to produce methane. To reduce methane production needs to inhibit growth of protozoa (Machmuller, 2006; Bhatta et al., 2013; Sondakh et al., 2015). However, several researchers indicated that reduction of methane production through protozoal defaunation caused some problems. This was because of the role of protozoa in fibre fermentation and in maintaining rumen $\mathrm{pH}$ at the normal pH (Bhatta et al., 2013). In addition, protozoa was capable of using fermentable carbohydrate to sustain its life, and the protozoa was able to slow down the conversion of fermentatble carbohydrate into lactic acid by the bacteria; as a result, the rumen $\mathrm{pH}$ could be controlled or maintained at normal $\mathrm{pH}$.

Methane formation in the rumen was influenced not only by the methanogenic microbes, but also by the presence of hydrogen to react with carbon which was then oxidized to produce methane (Morgavi et al., 2010). The hydrogen was also used by the propionic bacteria producing propionate (Sondakh et al., 2015). These resulted a competition between methanogenic bacteria and propionic bacteria in using the hydrogen; and this was known as hydrogen - sink mechanism (HSM).

Competition for hydrogen use was not only for methane production in which methanogenic microbes competed with propionic bacteria, but also for hydrogenation of unsaturated fatty acid in the rumen. Rumen bacteria (lipolitic bacteria) in the rumen hydrolyzed fats yielding saturated and unsaturated fatty acids. The unsaturated fatty acids were then hydrogenated to C:18 saturated fatty acids. This hydrogenation process needs hydrogen and enzymes. This situation caused competitions for hydrogen among the methanogenic microbes, propionate bacteria and the bacteria hydrogenating unsaturated fatty acids. It is expected methane production can be reduced when cattle are fed with feed containing unsaturated fatty acids.

Cakalang fish oil containing fatty acid consists of capric acid $1.62 \%$, oleic acid $3.15 \%$, stearic acid $21.12 \%$, palmitic acid $0.63 \%$, elaidic acid $13.98 \%$, palmitoleinic acid $0.48 \%$, linoleic acid $1.33 \%$, arachidonic acid $24.78 \%$, and lignoceric acid $0.49 \%$. Among these fatty acids, unsaturated fatty acid dominated content of fatty acid in fish oil for about $43.72 \%$. Therefore, it can be probable for hydrogenazing process by supplementation of cakalang fish oil. Therefore, the objective of this experiment is to reduce methane production through hydrogenation process.

\section{MATERIALS AND METHODS}

\section{Materials}

Materials used in this experiment were ruminal fluid, cakalang fish oil (CFO), feed consisting of forage (napier grass) and concentrate (rice bran), and materials (solutions) for fermentation gas test, and analysis of gas production and fatty acid profiles. Ruminal fluid was taken from the rumen of ruminant. The CFO was taken from the extraction of CFO industry. Feeds composing of napier grass and rice bran at a ratio of $60: 40$.

\section{Treatments}

Treatments applied in this experiment were R0: feed composing of forage and concentrate at a ratio of $60 \%: 40 \%$ with $0 \% \mathrm{CFO}$ as control ration; $\mathrm{R} 1$ : R0 supplemented with 2.5\% CFO; R2: R0 supplemented with 5\% CFO; and R3: R0 supplemented with 7.5\% CFO. All treatments of CFO were in dry matter (DM) and every treatments were conducted in four replications. Composition of experimental ration was listed in Table 1.

\section{Procedure}

Medium for fermentation was prepared by mixing $474.0 \mathrm{~mL}$ of distilled water, $0.12 \mathrm{~mL}$ of trace mineral, 237 $\mathrm{mL}$ of buffer, $1.22 \mathrm{~mL}$ of resazurin, and $49.5 \mathrm{~mL}$ of reducer solution. All the materials were homogenized and flowed with $\mathrm{CO}_{2}$ to achieve anaerobic conditions. The medium solution was then mixed with ruminal fluid at a ratio of 2 : 1 (v.v) (Menke \& Steingass, 1988).

Each treatment feed $(300 \mathrm{mg})$ was placed into a fermentation syringe which was subsequently added with a mixture of rumen fluid and fermentation medium $(30 \mathrm{~mL})$. All syringes containing treatement feeds were incubated at $39{ }^{\circ} \mathrm{C}$ for 72 hours. At the end of fermentation time, the fluids were filtered to separate the fluids

Tabel 1. Composition of experimental rations

\begin{tabular}{lrrrr}
\hline \multirow{2}{*}{ Variables } & \multicolumn{5}{c}{ Treatments } \\
\cline { 2 - 5 } & \multicolumn{1}{c}{ R0 } & \multicolumn{1}{c}{ R1 } & \multicolumn{1}{c}{ R2 } & \multicolumn{1}{c}{ R3 } \\
\hline Feedstuff & & & & \\
$\quad$ Forage (\%) & 60.00 & 60.00 & 60.00 & 60.00 \\
$\quad$ Concentrate (\%) & 40.00 & 40.00 & 40.00 & 40.00 \\
Nutrient ingredients & & & & \\
$\quad$ Crude protein (\%) & 12.16 & 12.16 & 12.16 & 12.16 \\
$\quad$ Crude fat (\%) & 4.28 & 4.28 & 4.28 & 4.28 \\
$\quad$ Crude fiber & 21.60 & 21.60 & 21.60 & 21.60 \\
$\quad$ Nitrogen free extract & 41.45 & 41.45 & 41.45 & 41.45 \\
$\quad$ (\%) & & & & \\
$\quad$ Ash (\%) & 8.10 & 8.10 & 8.10 & 8.10 \\
Adding CKO (\%) & 0.00 & 2.50 & 5.00 & 7.50 \\
\hline
\end{tabular}

Note: CFO: cakalang fish oil; R0: feed added with 0\% CFO; R1: R0 added with 2.5\% CFO; R2: R0 added with 5\% CFO; and R3: R0 added with $7.5 \% \mathrm{CFO}$; $\mathrm{CFO}$ in dry matter. 
from the solid matter. The fluids were then used for analysing methane gas production, $\mathrm{pH}$, fatty acid profile, and protozoal numbers.

Methane gas was measured with gas chromatography (GC, Hitachi 263 - 50). Sample of fermentation fluid $(1 \mathrm{~mL})$ was injected into GC using a spoit. The GC was conditioned as follows: $1 \mathrm{~mm}$ height of active carbon column, $0.5 \mathrm{~m}$ diameter, $190{ }^{\circ} \mathrm{C}$ detector temperature, $190{ }^{\circ} \mathrm{C}$ injector temperature, $150{ }^{\circ} \mathrm{C}$ column temperature, and $50 \mathrm{~mL} / \mathrm{min}$ nitrogen gas. The methane gas production was measured using this formula: (area of standard $x$ area of sample)/area of standard (Lopez et al., 1996).

$\mathrm{pH}$ was measured using $\mathrm{pH}$ meter. Fatty acid profiles were analyzed with GC. Protozoal numbers were counted using $1 \mathrm{~mL}$ of samples that were mixed previously with formal ssaline solution (1 : 9 ratio). Formal saline solution was prepared by mixing $0.8 \mathrm{~mL}$ formaldehyde (37 \% v.v) with $0.9 \%(\mathrm{w} / \mathrm{v}) \mathrm{NaCl}$ solution up to $100 \mathrm{~mL}$. Each sample was then put in a hemacytometer using a Pasteur pipet, and was placed under a microscope with $40 \mathrm{x}$ magnification (Diaz et al., 1993).

After taking the fluid samples for measuring methane production and fatty acid profiles, the samples were then centrifuged at 3,000 g for 15 minutes. Supernatants were used to determine VFA and $\mathrm{NH}_{3}$ concentrations. The filtrates were then centrifuged at $10,000 \mathrm{~g}$ for 15 minutes; supernatants were discarded, and the filtrates were used to measure microbial protein synthesised.

Concentration of $\mathrm{NH}_{3}$ was analysed using $0.5 \mathrm{~mL}$ of samples centrifuged at 3,000 $\mathrm{g}$ following Charney \& Marbach (1962) method. That sample was centrifuged at $10,000 \mathrm{~g}$ for $10 \mathrm{~min}$, then $20 \mu \mathrm{L}$ supernatant was added with $2.5 \mathrm{~mL} \mathrm{LC}$ and $2.5 \mathrm{~mL} \mathrm{LD}$, and mixed homogenously. That mixture was incubated in a waterbath at $40{ }^{\circ} \mathrm{C}$ for 30 minutes. After blue colour was formed, the samples were taken to cool down in room temperature, then the absorbance of samples were measured using a spectrophotometer at $\lambda 630 \mathrm{~nm}$. LC was a mixture of $\mathrm{Na}$ - nitroprusside (50 mg) and phenol crystal (10 g) added with distilled water up to $1 \mathrm{~L}$ volume. LD was made up with $\mathrm{NaOH}$ pellet $(5 \mathrm{~g})$ an), $\mathrm{Na}_{2} \mathrm{HPO}_{4} 2 \mathrm{H}_{2} \mathrm{O}$ solution (36.7125 g diluted in $100 \mathrm{~mL}$ of distilled water) and 25 $\mathrm{mL}$ of $5 \%$ sodium hypochloride, which was then mixed homogenously and added with distilled water up to $1 \mathrm{~L}$ volume.

VFA concentrations were determined using GC (Doreau et al., 1993). Samples previously prepared by centrifuging at 3,000 $\mathrm{g}$ for 15 minutes were used as much as $0.2 \mathrm{~mL}$ which were added with metaphosphoric acid $(1 \mathrm{~mL})$. After mixing homogenously, the samples were centrifuged at $10,000 \mathrm{~g}$ for 10 minutes. Supernatants were used as samples injected into GC with $1 \mu \mathrm{L}$ and was then read VFA after 6 minutes.

Filtrates produced after centrifuging at 10,000 $\mathrm{g}$ were used for analysing microbial protein synthesis measured with Lowry method (Plummer, 1987). Sample $(0.5 \mathrm{~mL})$ was put into a test tube which was then added with $2.5 \mathrm{~mL}$ of Lowry I solution and was kept at room temperature for 10 minutes. This mixture was then added with $0.25 \mathrm{~mL}$ of Lowry II solution. After keeping the smaples at room temperature for 30 minutes, the sample absorbances were then read using spectropho- tometer at $\lambda 750 \mathrm{~nm}$. Lowry I solution contained 2\% $\mathrm{Na}_{2} \mathrm{CO}_{3}$ in $0.1 \mathrm{~N} \mathrm{NaOH}$ solution, $2 \%$ sodium tartrate, and $1 \% \mathrm{CuSO}_{4} 5 \mathrm{H}_{2} \mathrm{O}$ and was mixed in a ratio of $100: 1$ : 1. Lowry II solution composed of $1 \mathrm{~N}$ Folin mixed with distilled water at a ratio of $1: 1$.

\section{Experimental Design, Variables Measured, and Data Analysis}

The experiment was carried out in completely randomized design with four treatments as described above and four replications. Variables measured were methane production, fatty acid profiles, $\mathrm{pH}$, protozoal numbers, $\mathrm{NH}_{3}$ concentration, VFA concentration and microbial protein synthesis. Analysis of variance (ANOVA) was used for analyzing the data. Differences among treatment means were examined with Duncan multiple range test (Steel \& Torrie, 1980).

\section{RESULTS}

Table 2 shows effects of treatments on methane production, protozoal numbers, total and partial VFA concentrations, $\mathrm{NH}_{3}$ concentration, microbial protein synthesis and $\mathrm{pH}$ of rumen fluid. Treatments affected significantly protozoal numbers $(\mathrm{P}<0.05)$. Protozoal numbers reduced linearly from $0 \%$ to $2.5 \%$ and $2.5 \%$ to $5 \%$ and $7.5 \% \mathrm{CKO}$ additions. There were no differences in protozoal numbers when $\mathrm{CFO}$ was added at $5 \%$ and $7.5 \%$.

Methane productions was reduced significantly with the addition of $\mathrm{CFO}$ in feeds at different levels $(\mathrm{P}<0.05)$. Methane production was the highest in feed added with $0 \%$ CFO $(\mathrm{P}<0.05)$, but this did not differ from that of feed added with $2.5 \%$ CFO. Methane production then decreased significantly $(\mathrm{P}<0.05)$ at $5 \%$ and $7.5 \%$ CFO addition without any significant differences in methane production between $5 \%$ and $7.5 \% \mathrm{CFO}$ addition.

Small fluctuations were observed in acetic, propionic, butyric, and total VFA concentrations when feeds were added with $0 \%, 2.5 \%, 5 \%$, and $7.5 \%$ CFO. However, differences among the levels of CFO additions were not statistically significant. These results did not cause any significant differences in acetate : propionate ratios among the treatments.

$\mathrm{NH}_{3}$ concentrations were influenced by addition of $\mathrm{CFO}$ at different levels into feeds $(\mathrm{P}<0.05)$. The highest $\mathrm{NH}_{3}$ concentration was produced by feed containing $0 \%$ $\mathrm{CFO}$, and the lowest $\mathrm{NH}_{3}$ concentration was yielded by feed added with $7.5 \% \mathrm{CFO}$. $\mathrm{NH}_{3}$ concentrations did not differ significantly when CFO was added at $0 \%, 2.5 \%$ and $5 \%$, or when CFO was added at $2.5 \%, 5 \%$ and $7.5 \%$.

There were no significant effects of adding CFO at $0 \%, 2.5 \%, 5 \%$, and $7.5 \%$ into the feeds on microbial protein synthesis. The same results were also observed in rumen fluid $\mathrm{pH}$.

Effects of addition of $\mathrm{CFO}$ at $0 \%, 2.5 \%, 5 \%$, and $7.5 \%$ on fatty acid profiles are demonstrated in Table 3. The addition of CFO at $0 \%, 2.5 \%, 5 \%$ and $7.5 \%$ did not affect productions of .lauric (C:12) and myristic (C:14) acids. On the other hand, the treatments affected other 
Table 2. Methane production, protozoal numbers, total and partial VFA concentrations, $\mathrm{NH}_{3}$ concentration, microbial protein synthesis, and rumen fluid $\mathrm{pH}$ treated with cakalang fish oil addition

\begin{tabular}{lcccc}
\hline \multicolumn{1}{c}{ Variables } & \multicolumn{2}{c}{ Treatments } \\
\cline { 2 - 5 } & \multicolumn{1}{c}{ R0 } & R1 & R2 & $18.77 \pm 0.50^{\mathrm{a}}$ \\
\hline Protozoal number $\left(\times 10^{3} \mathrm{~mL}\right)$ & $23.57 \pm 0.87^{\mathrm{c}}$ & $21.57 \pm 0.25^{\mathrm{b}}$ & $18.67 \pm 0.18^{\mathrm{a}}$ \\
Methane production (mL/g) & $23.77 \pm 0.75^{\mathrm{c}}$ & $22.44 \pm 0.27^{\mathrm{c}}$ & $20.83 \pm 0.78^{\mathrm{ab}}$ & $20.37 \pm 0.93^{\mathrm{a}}$ \\
VFA concentration $(\mathrm{mMol})$ & & & \\
$\quad$ Acetic acid & $22.87 \pm 0.31$ & $23.24 \pm 0.91$ & $22.02 \pm 0.67$ & $23.19 \pm 0.55$ \\
$\quad$ Propionic acid & $7.93 \pm 0.54$ & $8.97 \pm 0.54$ & $8.51 \pm 0.12$ & $8.67 \pm 0.09$ \\
$\quad$ Butyric acid & $2.85 \pm 0.18$ & $3.02 \pm 0.05$ & $3.04 \pm 0.17$ & $3.18 \pm 0.23$ \\
$\quad$ Total VFA & $33.65 \pm 0.71$ & $35.23 \pm 1.39$ & $33.57 \pm 0.91$ & $35.04 \pm 0.42$ \\
$\quad$ Acetate/propionate ratio & $2.89 \pm 0.18$ & $2.59 \pm 0.07$ & $2.58 \pm 0.05$ & $2.67 \pm 0.07$ \\
Microbial protein synthesis $(\mathrm{mg} / \mathrm{mL})$ & $0.50 \pm 0.08$ & $0.48 \pm 0.07$ & $0.42 \pm 0.03$ & $0.41 \pm 0.06$ \\
NH3 concentration (mg/100 mL) & $15.19 \pm 0.48^{\mathrm{b}}$ & $14.08 \pm 0.20^{\mathrm{ab}}$ & $13.12 \pm 0.42^{\mathrm{ab}}$ & $12.40 \pm 0.21^{\mathrm{a}}$ \\
Rumen fluid pH & $6.28 \pm 0.06$ & $6.47 \pm 0.17$ & $6.49 \pm 0.07$ & $6.41 \pm 0.15$ \\
\hline
\end{tabular}

Note: Means in the same row with different superscript differ significantly ( $\mathrm{P}<0.05)$. R0: feed added with $0 \%$ CFO; R1: R0 added with 2.5\% CFO; R2: R0 added with 5\% CFO; and R3: R0 added with $7.5 \%$ CFO.

Table 3. Fatty acid profile as affected by cakalang fish oil addition at different levels

\begin{tabular}{|c|c|c|c|c|}
\hline \multirow{2}{*}{ Fatty acids } & \multicolumn{4}{|c|}{ Treatments } \\
\hline & R0 & R1 & $\mathrm{R} 2$ & R3 \\
\hline & \multicolumn{4}{|c|}{ - } \\
\hline Lauric acid (C12:0) & $0.25 \pm 0.02$ & $0.22 \pm 0.01$ & $0.24 \pm 0.01$ & $0.32 \pm 0.01$ \\
\hline Miristic acid (C14:0) & $2.35 \pm 0.06$ & $2.50 \pm 0.16$ & $2.48 \pm 0.08$ & $2.33 \pm 0.09$ \\
\hline Palmitic acid (C16:0) & $18.75 \pm 0.20^{\mathrm{a}}$ & $18.91 \pm 0.33^{a}$ & $19.41 \pm 0.31^{\mathrm{ab}}$ & $20.39 \pm 0.55^{b}$ \\
\hline Stearic acid (C18:0) & $24.15 \pm 1.90^{\mathrm{a}}$ & $26.09 \pm 1.14^{\mathrm{b}}$ & $28.11 \pm 0.92^{\mathrm{b}}$ & $28.31 \pm 1.22^{\mathrm{b}}$ \\
\hline Oleic acid (C18:1) & $13.88 \pm 0.59^{a}$ & $14.09 \pm 0.69^{a}$ & $15.35 \pm 0.64^{\mathrm{ab}}$ & $16.74 \pm 0.79^{c}$ \\
\hline Linoleic acid (C18:2) & $5.91 \pm 0.24^{\mathrm{a}}$ & $6.18 \pm 0.23^{\mathrm{a}}$ & $7.08 \pm 0.19^{b}$ & $7.30 \pm 0.30^{\mathrm{b}}$ \\
\hline Linolenic acid (C18:3) & $0.37 \pm 0.03^{\mathrm{a}}$ & $0.41 \pm 0.03^{\mathrm{ab}}$ & $0.61 \pm 0.02^{\mathrm{b}}$ & $0.74 \pm 0.04^{c}$ \\
\hline Total of fatty acids & $65.66 \pm 1.01^{\mathrm{a}}$ & $69.23 \pm 2.05^{\mathrm{b}}$ & $73.24 \pm 0.63^{\mathrm{bc}}$ & $76.06 \pm 1.94^{c}$ \\
\hline SFA & $45.50 \pm 1.30^{\mathrm{a}}$ & $48.54 \pm 1.89^{b}$ & $50.20 \pm 0.57 b$ & $51.28 \pm 1.70^{c}$ \\
\hline UFA & $20.16 \pm 0.82^{\mathrm{a}}$ & $20.69 \pm 0.85^{\mathrm{a}}$ & $23.04 \pm 0.45^{b}$ & $24.69 \pm 0.58^{c}$ \\
\hline SFA/UFA ratio & $2.26 \pm 0.15$ & $2.35 \pm 0.13$ & $2.18 \pm 0.05$ & $2.07 \pm 0.07$ \\
\hline
\end{tabular}

Note: SFA: saturated fatty acids; UFA: unsaturated fatty acids; Means in the same row with different superscript differ significantly (P<0.05). R0: feed added with $0 \%$ CFO; R1: R0 added with 2.5\% CFO; R2: R0 added with 5\% CFO; and R3: R0 added with 7.5\% CFO.

fatty acid productions $(\mathrm{P}<0.05)$ by increasing productions of palmitic (C16:0), stearic (C18:0), oleic (C18:1), linoleic (C18:2) and linolenic (C18:3) acids.

Production of palmitic acid (C16:0) were not different when feeds were added with $0 \%, 2.5 \%$, and $5 \%$. This palmitate production then increased to the highest level when $7.5 \%$ CFO was added into the feed $(\mathrm{P}<0.05)$; however, there were no significant differences in palmitate productions between $5 \%$ and $7.5 \%$ CFO additions. The same effects of CFO addition at different levels as those found in palmitic acid production were also observed in oleic acid (C18:1) production.

Stearic acids (C18:0) were produced at the lowest level when feed was added with $0 \%$ CFO. Adding CFO from $2.5 \%$ up to $7.5 \%$ in feed increased stearic acid productions $(\mathrm{P}<0.05)$, but the differences in stearic acid productions among the three treatments were not significant. The trends in stearic acid productions as affected by $\mathrm{CFO}$ addition were also observed in linoleic acid (C18:2) productions.

Addition of $\mathrm{CFO}$ at different levels affected significantly $(\mathrm{P}<0.05)$ linolenic acid $(\mathrm{C} 18: 3)$ production. The lowest linolenic acid production was obtained when CFO was added at $0 \%$. Adding $2.5 \%$ CFO increased linolenic acid production, but this increase was not different from that of $0 \% \mathrm{CFO}$ addition. A further increase in linolenic acid production was obtained by increasing the CFO level to $5 \%$, but there were no differences in linolenic acid production between CFO addition at $2.5 \%$ and at $5 \%$, or between CFO addition at $5 \%$ and $7.5 \%$. Differences in linolenic acid production were observed between $\mathrm{CFO}$ addition at $2.5 \%$ and that at $7.5 \%(\mathrm{P}<0.05)$.

Addition of CFO from $0 \%$, to $2.5 \%, 5 \%$, and up to $7.5 \%$ affected total fatty acid production $(\mathrm{P}<0.05)$. The lowest production of total fatty acid was obtained from feed added with $0 \%$ CFO $(\mathrm{P}<0.05)$, this production 
then increased when feed was added with $2.5 \%$ CFO $(\mathrm{P}<0.05)$. Further increases in total fatty acid production were obtained by adding $5 \%$ and $7.5 \%$ CFO, but there were no differences in total fatty acid production obtained from $5 \%$ and from $7.5 \%$ CFO addition.

Saturated fatty acid (SFA) production was affected by adding $\mathrm{CFO}$ at different levels $(\mathrm{P}<0.05)$. Adding $0 \%$ CFO produced the lowest SFA. SFA production increased with CFO addition levels, but differences in SFA production between $2.5 \%$ and $5 \%$, or between $5 \%$ and 7.5\% CFO additions were not significant.

Unsaturated fatty acid production (UFA) was also affected by addition of $\mathrm{CFO}$ at different levels $(\mathrm{P}<0.05)$. The lowest UFA was produced when CFO was added at $0 \%$, and the highest was obtained by adding CFO at $7.5 \%$. Similar UFA productions were obtained between $2.5 \%$ and $5 \%$, or between $5 \%$ and $7.5 \%$ CFO additions.

Although there were effects of CFO addition of SFA and UFA productions. these did not cause any significant differences in the ratio between SFA and UFA among the levels of CFO addition.

\section{DISCUSSION}

Reduction in protozoal numbers by adding CFO at different levels had been indicated in this experiment meaning that supplementing with $\mathrm{CFO}$ as unsaturated fatty acids from animal products had reduced the protozoal numbers, and this became another attempt of defaunation. The effects of CFO supplementation as unsaturated fatty acid source were similar to those obtained by Hristov et al. (2004) and Cieslak et al. (2006) using unsaturated fatty acids from plant sources.

Hristov et al. (2004) stated that the use of unsaturated fatty acid containing more double bonds was capable of reducing protozoal numbers in the rumen. Those researchers also reported that supplementationwith monounsaturated fatty acid (MUFA) such as oleic acid, and polyunsaturated fatty acid such as linoleic acid, had reduced protozoal numbers, respectively, by $10.74 \%$ and $14.90 \%$. In addition, Cieslak et al. (2006) showed that protozoal numbers also reduced by $30.77 \%$ and $36.15 \%$, respectively, by supplementing feed at a level of $7.5 \%$ with rapeseed oil containing $62 \%$ oleic acid or linseed oil containing 53\% linolenic acid. Reductions in protozoal numbers were due to ability of unsaturated fatty acid to inhibit protozoal growth (Gao et al., 2016), and the unsaturated fatty acids containing C18 in high amount could be toxic for protozoa in the rumen (Varadyova et al., 2007). These reductions in protozoal numbers may contribute to the reductions in methane productions.

Reductions in methane productions was due to the effects of CFO additions. This CFO contained high amounts of unsaturated fatty acids composing of oleic, linoleic and linolenic acids having double bonds in its structures. These double bonds became the site for hydrogenation after lipids were hydrolyzed into fatty acids. Hydrogenation of double bonds in unsaturated fatty acids produced hydrogens that were used for saturated fatty acid formation. However, hydrogens were not only used for saturated fatty acid formation, but also for producing methane gas by methanogenic bacteria and for propionate production by propionic bacteria (Sondakh et al., 2015). This may cause a competition for hydrogen utilization.

Additions of CFO at different levels as the source of unsaturated acids did not affect concentrations of total and partial VFA. Ratios of acetate to propionate in this study were in the range of 2.58-2.89 which were less than 3.125 for normal rumen condition as suggested by Hungate et al. (1975). Low ration in this study can be due to the increase of propionic acid after adding of feed substrate in CFO. The effect of unsaturated fatty acid addition on total and partial VFA concentrations was not in an agreement with Sitoresmi et al. (2009) and Harwanto et al. (2014). This was because addition of unsaturated fatty acids, types, and substrate proportion affected total VFA concentrations. Other factors, such as the ratio of napier grass and concentrate in $60 \%: 40 \%$, may also affect total and partial VFA concentrations.

Microbial protein synthesis in this study were in the range of $0.41-0.50 \mathrm{mg} / \mathrm{mL}$ indicating no effects of CFO addition on microbial protein synthesis. Those microbial protein synthesis were still higher than those obtained by Sondakh et al. (2015) which were 0.24-0.27 $\mathrm{mg} / \mathrm{mL}$ by supplementing with VCO (a medium-chain fatty acid source) at $8 \%$. Higher microbial protein synthesis $(0.39-0.40 \mathrm{mg} / \mathrm{mL})$ were obtained by using vegetable oil supplementation at $7.5 \%$ (Sitoresmi et al., 2009). The precursors needed for microbial protein synthesis were carbon, $\mathrm{NH}_{3^{\prime}}$ and energy in sufficient amount (Orskov, 1992).

The $\mathrm{NH}_{3}$ concentration in this study were $12.40-15.19 \mathrm{mg} / 100 \mathrm{~mL}$. Although, it was indicating that there was decrease of $\mathrm{NH}_{3}$ after adding $\mathrm{CFO}$, the range of $\mathrm{NH}_{3}$ in this study were still in normal range. This agreed with Harfiah (2006) stating that normal activity of microbia needed ammonia concentration of 8.5 to 30 $\mathrm{mg} / 100 \mathrm{~mL}$. These $\mathrm{NH}_{3}$ concentrations were less than that obtained by Sitoresmi et al. (2009) which were in the range of $33.24-34.53 \mathrm{mg} / 100 \mathrm{~mL}$ by supplementing with coconut oil, palm oil, and sunflower oil at $7.5 \%$.

Addition of $\mathrm{CFO}$ at increasing levels could still manage rumen fluid $\mathrm{pH}$ at its normal range. Owen \& Zinn (1988) stated that normal rumen fluid $\mathrm{pH}$ was 5.57.6 for supporting normal activity of rumen micobes in degrading and fermenting the feeds. Sung et al. (2007) stated that the range of normal $\mathrm{pH}$ to ruminal metabolism were 6-7. This could relate to the $\mathrm{pH}$ for optimum enzyme activity in the rumen, such as 5.5-7.0 for peptidase and 6.2-7.0 for cellulose, and other processes, such as VFA productions at 6.8-7.0 (Keidane \& Birgele, 2003), and increase in unesterified fatty acids at 6.97 and 7.35 (Hristov et al., 2004).

In this study, the addition of 5\% CFO has been able to reduce methane production, whereas the number of protozoa decreased at the addition of $7.5 \%$. Highest decrease in the number of protozoa will exacerbate rumen metabolism process. It was also indicated by $\mathrm{NH}_{3}$ concentration which was decreased at addition 7.5\% CFO. Addition of 7.5 CFO indicated a bad condition due to low amount of $\mathrm{NH}_{3}$.

CFO addition, especially at the highest levels $(7.5 \%)$, had changed the fatty acid profiles. The changes 
were in relation to the contents and amounts of unsaturated fatty acids that affected biohydrogenation in the rumen. Wasowska et al. (2006) stated that the presence of unsaturated fatty acids inhibited biohydrogenation.

\section{CONCLUSION}

The addition of CFO reduced protozoal numbers, methane gas production, $\mathrm{NH}_{3}$ concentration and fatty acid profile without any effects on total and partial VFA concentrations, microbial protein synthesis and rumen fluid $\mathrm{pH}$. The greater effects were produced by $\mathrm{CFO}$ addition at $7.5 \%$, and the effects were similar to those obtained by $\mathrm{CFO}$ addition at $5 \%$. Therefore, it is recommended to use $\mathrm{CFO}$ at $5 \%$ as unsaturated fatty acid source in feed composing of napier grass and concentrate at $60 \%: 40 \%$ ratio.

\section{ACKNOWLEDGEMENT}

Directorate General of Higher Education, Ministry of Research and Higher Education, is acknowledged for the funding support through the scheme of Fundamental Research 2017. Appreciation also present to Ir. Anita S. Tjakradidjaja, M.Rur.Sc. for her contribution on improving the language of this manuscript.

\section{REFERENCES}

Bhatta, R., M. Saravanan, L. Baruah, K.T. Sampath, \& C.S. Prasad. 2013. Effect of plant secondary compounds on in vitro methane, ammonia production and ruminal protozoa population. J App. Microbiol. 115: 455-465.

Chaney, A.L., \& E.P. Marbach. 1962. Modified reagents for determination of urea and ammonia. Clin. Chem. 8:130-132.

Cieslak, A., R. Miltko, G. Belzecki, \& E. Kwiatkowska. 2006. Effect of vegestable oils on the methane concentration and population density of the rumen ciliate, Eremoplastron dilobum, grown in vitro. J. Anim. Feed Sci. 15: 15-18. https:// doi.org/10.22358/jafs/70132/2006

Diaz, A., M. Avendano, \& A. Escobar. 1993. Evaluation of sapindus saponaria as a defaunating agent and its effects on different ruminal digestion parameters. Livest. Res. Rural Dev. 5: 1-6.

Dohme, F., A. Machmuller, B.L. Esterman, P. Pfister, A. Wasserfallen, \& M. Kreuzer. 1999. The rule of the rumen protozoa for methane suppression caused by coconut oil. Lett. App. Microbiol. 29:87-192. https://doi. org/10.1046/j.1365-2672.1999.00614.x

Doreau, M., B. Salem, \& R. Krezminski. 1993. Effect of rapeseed oil supply on in vitro ruminal digestion in cows: comparison of hay and maize silage diets. Anim. Feed Sci. Technol. 44:181-189. https://doi.org/10.1016/0377-8401(93)90046-M

Gao, J., M.Z. Wang, Y.J. Jing, X.Z. Sun, T.Y. Wu, \& L.F. Shi. 2016. Impacts of the unsaturation degree of long-chain fatty acids on the volatile fatty acid profiles of rumen microbial fermentation in goats in vitro. J Integrative Agric. 15: 2827-2833. https://doi.org/10.1016/S2095-3119(16)61418-1

Harfiah. 2006. Perbandingan daya cerna in vitro bahan kering rumput gajah dan hasil fermentasi campuran rumput lapangan dengan isi rumen. J. Sci. Ethiol. 6: 67-70

Harwanto., L.M. Yusiati, \& R. Utomo. 2014. Pengaruh kayu manis (Cinnamomumburmanni Ness ex BI.) sebagai sumber sinamaldehid terhadap parameter fermentasi dan aktivitas mikrobia rumen secara in vitro. Buletin Peternakan 38:71-77
Hristov, A.N., M. Ivan, \& T. McAllister. 2004. In vitro effects on individual fatty acids on protozoal numbers and on fermentation products in ruminal fluid from cattle fed a high concentrate, barley-based diet. J. Anim. Sci. 82:2693-2704. https://doi.org/10.2527/2004.8292693x

Hungate, R.E. 1975. The rumen microbial ecosystem. Anim. Rev. Ecology Systematics 6:39-66. https://doi.org/10.1146/ annurev.es.06.110175.000351

Kamra, D.N. 2005. Rumen microbial ecosystem. Special edition: Microbial Diversity. Current Sci. 89:124-135.

Keidane, D., \& E. Birǵele. 2003. The efficacy of feed on the intra abomasal $\mathrm{pH}$ dynamics in goats. Veterinarija IR Zootechnica 22:58-61

Lopez, P., M.L. Kung Jr., \& J.M. Odom. 1996. In vitro of microbial methane production by 9,10 -anthraquinone. Anim. Feed Sci. Technol 71: 117-130

Machmuller, A. 2006. Medium-chain fatty acids and their potensial to reduce methanogenesis in domestic ruminants. Agr. Ecosyst. Environ. 112:107-114. https://doi.org/10.1016/j. agee.2005.08.010

McDonald, P., P.A. Edwards, \& J.F.D. Greenhalg. 1988. Animal Nutrition. $4^{\text {th }}$ ed. Longman Sci. and Tech. New York.

Menke, K.H., \& H. Steingass. 1988. Estimation of energetic feed value obtained from chemical analysis and in vitro gas production using rumen fluid. Anim. Res. Develop. 28: 7-55

Morgavi, D.P., E. Forano, C. Martin, \& C.J. Newbold. 2010. Microbial ecosystem and methanogenesis in ruminants. Animal 4: 1024-1036. https://doi.org/10.1017/ S1751731110000546

Orskov, E.R. 1992. Protein Nutrition in Ruminant. Academic Press Limited. London

Owen, F.N., \& R. Zinn. 1988. Protein metabolism of Ruminant animals. In: D.C. 314 Church (Ed), The Ruminant animal Digestive physiology and Nutrition. Reston 315 Book Prentice Hall, Englewood Cliffs, New Jersey.

Plummer, D.T. 1987. An Introduction to Practical Biochemistry. 3rd ed. McGraw-Hill Book Company. London.

Sitoresmi, P.D., L.M. Yusiati, \& H. Hartadi. 2009. Pengaruh penambahan minyak kelapa, minyak biji matahari, dan minyak kelapa sawit terhadap penurunan produksi metan di dalam rumen secara in vitro. Buletin Peternakan 33: 96105. https://doi.org/10.21059/buletinpeternak.v33i2.122

Sondakh, E.H.B., L. M. Yusiati, H. Hartadi, \& E. Suryanto. 2012. The effect of methanogenic inhibitor feed on propionic acid and lamb meat chemical quality. J. Indonesian Trop. Anim. Agric. 37: 183-188. https://doi.org/10.14710/ jitaa.37.3.183-188

Sondakh, E.H.B., J.A. Rorong, \& J.A.D. Kalele. 2015. Methane gas reduction using virgin coconut oil supplementation in rumen fermentation through in vitro. J. Anim. Prod. 17:144148. https://doi.org/10.20884/1.anprod.2015.17.3.511

Steel, R.G.D., \& J.H. Torrie. 1980. Principles and Procedures of Statistics. McGraw-Hill Book Co. Inc. New York.

Sung, H.G., Y. Kobayashi, J. Chang, A. Ha, I.H. Hwang, \& J.K. Ha. 2007. Low ruminal $\mathrm{pH}$ reduces dietary fiber digestion via reduced microbial attachment. J. Anim. Sci. 20: 200-207. https://doi.org/10.5713/ajas.2007.200

Varadyova, Z., S. Kišidayova, P. Siroka, \& D. Jalč. 2007. Fatty acid profiles of rumen fluid from sheep fed diets supplemented with various oils and effect on the rumen ciliate population. Czech J. Anim. Sci. 52: 399-406.

Wasowska, I., M.R.G. Maia, K.M. Niedźwiedzka, M. Czauderna, J.M.C. Ramalho Ribeiro, \& E. Devillard. 2006. Influence of fish oil on ruminal biohydrogenation of C18 unsaturated fatty acids. Br. J. Nutr. 95:1199-1211. https://doi.org/10.1079/BJN20061783 